University of Nebraska - Lincoln

DigitalCommons@University of Nebraska - Lincoln

November 1993

\title{
Fractal Description of Soil Fragmentation for Various Tillage Methods and Crop Sequences
}

\author{
Bahman Eghball \\ USDA-ARS \\ Lloyd N. Mielke \\ USDA-ARS \\ Guillermo A. Calvo \\ USDA-ARS \\ Wallace Wilhelm \\ University of Nebraska-Lincoln, wwilhelm1@unl.edu
}

Follow this and additional works at: https://digitalcommons.unl.edu/usdaarsfacpub

Part of the Agricultural Science Commons

Eghball, Bahman; Mielke, Lloyd N.; Calvo, Guillermo A.; and Wilhelm, Wallace, "Fractal Description of Soil Fragmentation for Various Tillage Methods and Crop Sequences" (1993). Publications from USDA-ARS / UNL Faculty. 82.

https://digitalcommons.unl.edu/usdaarsfacpub/82

This Article is brought to you for free and open access by the U.S. Department of Agriculture: Agricultural Research Service, Lincoln, Nebraska at DigitalCommons@University of Nebraska - Lincoln. It has been accepted for inclusion in Publications from USDA-ARS / UNL Faculty by an authorized administrator of DigitalCommons@University of Nebraska - Lincoln. 


\title{
DIVISION S-6-SOIL \& WATER MANAGEMENT \& CONSERVATION
}

\author{
Fractal Description of Soil Fragmentation for Various Tillage Methods \\ and Crop Sequences
}

\author{
Bahman Eghball,* Lloyd N. Mielke, Guillermo A. Calvo, and W. W. Wilhelm
}

\begin{abstract}
Soil structure has been difficult to quantify and, at best, has been studied semiquantitatively. Fractal representation of soil fragmentation can provide an indication of soil structure. The purpose of our study was to use fractal analysis to quantify soil fragmentation under various tillage and crop sequence treatments at different times during the growing season. We collected soil samples from four tillage treatments (established $10 \mathrm{yr}$ earlier) of chisel, disk, no-till, and moldboard plow in factorial arrangement with two crop sequences of corn (Zea may L.)-soybean [Glycine max (L.) Merr.]-corn (C-S-C), and soybean-corn-soybean, (S-C-S) on a Sharpsburg (fine, montmorillonitic, mesic Typic Argiudoll) soil. Aggregate-size distribution was used to calculate fractal dimension $(D)$ for each treatment. Higher $D$ values indicate greater soil fragmentation and a soil dominated by smaller aggregates. The opposite is true for lower $D$ values. Differences in soil fragmentation observed for tillage treatments after autumn tillage became even greater over winter. Soil fragmentation increased over autumn and winter, with $D$ increasing in the order of plow > chisel > disk > no-till. Formation of larger soil aggregates increased during the growing season for all tillage systems. The $D$ values for $C-S-C$ were smaller than $\mathbf{S}-\mathrm{C}-\mathrm{S}$ in the no-till, indicating that the previous year's corn in C-S-C provided more large aggregates. Soybean appears to have negative effects on large-aggregate formation in no-till. Aggregate densities, averaged across tillage and crop sequence, increased from 1.25 to $1.77 \mathrm{Mg} \mathrm{m}^{-3}$ as the aggregate diameter decreased from 6.38 to $0.162 \mathrm{~mm}$. Fractal analysis was found to be useful in determining soil fragmentation differences due to different tillage methods and crop sequences.
\end{abstract}

$\mathrm{T}$ HE DISTRIBUTION OF AGGREGATES of different sizes, abbreviated to aggregate-size distribution, is a consequence of soil structure and is a potentially useful way of expressing structure quantitatively. Fractal analysis, which is based on self-similarity (the manner in which variations on one scale are repeated at another), has been applied to soil since soil is both a fragmented material and a porous medium (Mandelbrot, 1983; Tyler and Wheatcraft, 1989; Rieu and Sposito, 1991a). Fractal representation of soil is based on pore-space and particle-size distribution, which are useful ways of quantifying soil structure. In this representation, the fractal dimension is an indicator of soil fragmentation and subsequently of soil structure.

Rieu and Sposito (1991a) mathematically developed two fractal dimensions for the soil system based on the degree of soil fragmentation. These are $D_{\mathrm{r}}$, the

USDA-ARS, Dep. of Agronomy, Univ. of Nebraska, Lincoln, NE 68583. Contribution of the USDA-ARS in cooperation with the Nebraska Exp. Stn., Lincoln, NE, as Paper no. 9909. Received 3 Dec. 1992. "Corresponding author.

Published in Soil Sci. Soc. Am. J. 57:1337-1341 (1993). bulk fractal dimension of an incompletely fragmented soil system, and $D$, the fractal dimension of a completely fragmented soil or a soil whose aggregate-size distribution is being measured. A soil with clusters of size-scaled, similar partial volumes separated from one another by a network of size-scaled similar fractures is considered to have complete fragmentation (Rieu and Sposito, 1991a). Incomplete fragmentation is the case where there are interaggregate bridges in the fractures holding the aggregates together. According to Rieu and Sposito (1991a), the fractal dimension in soil is expected to be $<3$ since a solid volume with no porosity would have a dimension of 3 . Perfect and Kay (1991), however, indicated that the $D$ value determined from aggregate-size distribution is a measure of soil fragmentation and showed that it can be as high as 3.5. Generally, improving the structure of a soil would result in the formation of larger aggregates and a decrease in the soil fractal dimension.

Soil structure is difficult to quantify and has often been presented and discussed semiquantitatively, i.e., geometric mean diameter (Fahad et al., 1982). The purpose of this study was to quantify soil fragmentation, as an indicator of soil structure, for various tillage methods and crop sequences at different times during the growing season using fractal analysis.

\section{MATERIALS AND METHODS}

\section{Aggregate-Size Distribution}

A tillage-crop sequence experiment was started in 1978 at the University of Nebraska, Rogers Memorial Farm, near Lincoln, NE, on a Sharpsburg soil. The tillage treatments were chisel, disk, no-till, and plow in a randomized complete block with six replicates. Continuous corn was planted on the experimental area through 1984. In 1985 , each tillage plot was divided into four subplots ( $23 \mathrm{~m}$ long by $4.6 \mathrm{~m}$ wide each) to which four crop sequences were assigned. The crop sequences were $\mathrm{C}-\mathrm{C}-\mathrm{C}, \mathrm{C}-\mathrm{S}-\mathrm{C}, \mathrm{S}-\mathrm{C}-\mathrm{S}$, and $\mathrm{S}-\mathrm{S}-\mathrm{S}$. This made the experiment a split plot in a randomized complete-block design with tillage as the main plot and crop sequence as the subplot. Plow and chisel treatments were applied in the autumn and disk treatment was applied in the spring. All tilled treatments were disked in the spring prior to planting. Corn was planted on 2 May 1988 and 3 May 1989 and soybean was planted on 14 May in both years. Plots were under rainfed conditions. Weeds were controlled by herbicides in the no-till and by herbicides and cultivation in the tilled treatments. In 1988 and 1989 , soil samples were collected from the four tillage and two crop sequence ( $\mathrm{C}-\mathrm{S}-\mathrm{C}$ and $\mathrm{S}-\mathrm{C}-\mathrm{S}$ ) treatments (six replicates) for determination of aggregate-size distribution. Soy-

Abbreviations: C-S-C, corn-soybean-corn sequence; S-C-S, soybean-corn-soybean; C-C-C, corn-corn-corn; S-S-S, soybean-soybean-soybean. 
bean was growing in $\mathrm{C}-\mathrm{S}-\mathrm{C}$ and corn in $\mathrm{S}-\mathrm{C}-\mathrm{S}$ in 1988 while these were reversed in 1989. Three soil subsamples were taken from each plot with a bulk hand sampler, 108-mm i.d., to a depth of $80 \mathrm{~mm}$ and processed for aggregate-size distribution individually. Soil samples were collected at precultivation (Day 158), flowering (both crops, Day 205), physiological maturity (both crops, Day 256) and post autumn-tillage (Day 303) in 1988 and at prespring-tillage (Day 98), emergence (Day 144), and physiological maturity (Day 265) in 1989. Soil samples were stored in double plastic bags in a cold room at $4{ }^{\circ} \mathrm{C}$ constant temperature before determining aggregate-size distribution. The soil samples were spread on a shallow aluminum plate $(230-\mathrm{mm}$ diam.) and air dried in a glasshouse.

After air drying, $\approx 750 \mathrm{~g}$ of soil aggregates were separated by shaking the samples on nine sieves with different sized openings $(16,8,4.76,4,2,1,0.5,0.25$, and $0.074 \mathrm{~mm})$ for $30 \mathrm{~s}$. This was found to be the best shaking time to ensure passage of aggregates through the sieve openings and to minimize aggregate disruption (Calvo, 1991). Aggregates on each sieve were collected and weighed.

Soil samples were taken from three replicates of the tillage and crop sequence treatments in the spring of 1990 and were used to determine the density $\left(\sigma, \mathrm{Mg} \mathrm{m}^{-3}\right)$ of aggregates in different size classes. The samples were sieved to the same size classes as above and the density of each aggregate-size class was determined based on the bulk density method described by Chepil (1950). Aggregate density was determined for all size classes except aggregates of $>8$ and $<0.074 \mathrm{~mm}$ in diameter. Aggregate density was assumed to be similar for all sampling times.

\section{Fractal Analysis}

Aggregate-size distribution was determined based on the weight of soil in each size class $(>16,8-16,4.76-8,4-4.76$, $2-4,1-2,0.5-1,0.25-0.5,0.074-0.25$, and $<0.074 \mathrm{~mm})$ with respect to the total soil sample weight. In the fractal analysis, all the soil samples were adjusted to a total soil sample mass of $750 \mathrm{~g}$. Average weight of three subsamples for each plot was used for fractal analysis. A quantity proportional to the number of aggregates of each size class, $N\left(d_{i}\right)$, was calculated based on the following relationship given by Rieu and Sposito (1991b):

$$
N\left(d_{i}\right)=M\left(d_{i}\right) / d_{i}^{3} \sigma_{i} \quad(i=0,1 \ldots . .)
$$

where $M\left(d_{i}\right), d_{i}$, and $\sigma_{i}$ are the mass, mean diameter, and density of aggregates in the $i$ th size class, respectively. Size Class 0 contains the largest aggregates. Mean aggregate diameters and aggregate densities of size classes for the tillage methods and crop sequences that were used in the fractal analysis are given in Table 1.

The quantity $\left(N\left(d_{k}\right)\right.$, where

$$
N\left(d_{k}\right)=\Sigma N\left(d_{i}\right) \quad(i=0, \ldots k)
$$

and $d_{k}$ is the mean diameter of Size Class $i=k$, was used to estimate the fractal dimension, $D$, which is the negative slope of regression line of $\log N\left(d_{k}\right)$ vs. $\log \left(d_{k} / d_{\mathrm{g}}\right)$ (Perfect and Kay, 1991) for the tillage and crop sequence treatments. In this analysis, $d_{\mathrm{g}}$ is the diameter of the largest aggregates, while the regression line intercept indicates the quantity of the largest aggregates.

A test of homogeneity was performed on the data to determine if the $D$ values for the repeated observations of each treatment were homogeneous. After homogeneity was established, analysis of covariance (Winer, 1971), with $\log \left(d_{k} / d_{\mathrm{g}}\right)$ as covariant, was performed on the data to estimate $D$ and intercept for each treatment and also to determine differences between values of $D$ for different tillage and crop sequences using SAS (Miles-McDermott et al., 1988; SAS Institute, 1985). Interactions of $\log \left(d_{k} / d_{\mathrm{g}}\right)$ with tillage, crop sequence, and tillage $\times$ crop sequence were used to determine if values of $D$ within each treatment were different. Orthogonal contrasts were used to compare $D$ between levels of tillage and tillage $\times$ crop sequence. In the analysis of covariance, the tillage and crop sequence main effects and the tillage $\times$ crop sequence interaction test the equality of aggregate numbers at midpoints of the regression lines. A probability level of $\leq 0.10$ was considered significant.

\section{RESULTS AND DISCUSSION}

Aggregate densities for the two crop sequence systems were not significantly different at all size classes (Table 1 ). The density of aggregates from no-till (lowest density) was smaller by $6.5,3.9$, and $3.4 \%$ than the tillage system with the highest density at 1- to $2-, 0.5-$ to $1-$, and $0.25-$ to $0.5-\mathrm{mm}$ aggregate-size classes, respectively. This may have occurred because organic $\mathrm{C}$ in the no-till tended to be greater than for other tillage treat-

\begin{tabular}{|c|c|c|c|c|c|c|c|}
\hline \multirow[b]{2}{*}{ Variable } & \multicolumn{7}{|c|}{ Aggregate density } \\
\hline & $\begin{array}{l}4.76-8 \mathrm{~mm} \\
(6.38) \dagger\end{array}$ & $\begin{array}{c}4-4.76 \mathrm{~mm} \\
(4.38)\end{array}$ & $\begin{array}{c}2-4 \mathrm{~mm} \\
\text { (3) }\end{array}$ & $\begin{array}{c}1-2 \mathrm{~mm} \\
(1.5)\end{array}$ & $\begin{array}{c}0.5-1 \mathrm{~mm} \\
(0.75)\end{array}$ & $\begin{array}{c}0.25-0.5 \mathrm{~mm} \\
(0.375)\end{array}$ & $\begin{array}{c}0.074-0.25 \mathrm{~mm} \\
(0.162)\end{array}$ \\
\hline & & & & Mg m & & & \\
\hline \multicolumn{8}{|l|}{ Tillage (Till) } \\
\hline $\begin{array}{l}\text { Chisel } \\
\text { Disk } \\
\text { No-till } \\
\text { Plow } \\
\text { LSD(0.10) }\end{array}$ & $\begin{array}{l}1.26 \\
1.23 \\
1.23 \\
1.25 \\
0.08\end{array}$ & $\begin{array}{l}1.29 \\
1.28 \\
1.26 \\
1.34 \\
0.10\end{array}$ & $\begin{array}{l}1.45 \\
1.44 \\
1.42 \\
1.50 \\
0.10\end{array}$ & $\begin{array}{l}1.65 \\
1.60 \\
1.57 \\
1.68 \\
0.04\end{array}$ & $\begin{array}{l}1.78 \\
1.75 \\
1.71 \\
1.74 \\
0.04\end{array}$ & $\begin{array}{l}1.77 \\
1.76 \\
1.71 \\
1.73 \\
0.03\end{array}$ & $\begin{array}{l}1.79 \\
1.77 \\
1.76 \\
1.77 \\
0.06\end{array}$ \\
\hline \multicolumn{8}{|l|}{ Crop sequence (CS) } \\
\hline $\begin{array}{l}\mathrm{C}-\mathrm{S}-\mathrm{C} \ddagger \\
\mathrm{S}-\mathrm{C}-\mathrm{S}\end{array}$ & $\begin{array}{l}1.24 \\
1.25\end{array}$ & $\begin{array}{l}1.30 \\
1.29\end{array}$ & $\begin{array}{l}1.44 \\
1.47\end{array}$ & $\begin{array}{l}1.62 \\
1.63\end{array}$ & $\begin{array}{l}1.75 \\
1.74\end{array}$ & $\begin{array}{l}1.75 \\
1.73\end{array}$ & $\begin{array}{l}1.78 \\
1.76\end{array}$ \\
\hline \multicolumn{8}{|c|}{ Analysis of variance, $P>F$} \\
\hline $\begin{array}{l}\text { Replicate (R), } 2 \text { df } \\
\text { Tillage, } 3 \mathrm{df} \\
\mathrm{R} \times \text { Tillage, } 6 \mathrm{df}\end{array}$ & $\begin{array}{l}0.09 \text { 1 } \\
0.89\end{array}$ & $\begin{array}{l}0.36 \\
0.50\end{array}$ & $\begin{array}{l}0.94 \\
0.49\end{array}$ & $\begin{array}{l}0.35 \\
0.01\end{array}$ & $\begin{array}{l}0.16 \\
0.08\end{array}$ & $\begin{array}{l}0.09 \\
0.02\end{array}$ & $\begin{array}{l}0.75 \\
0.72\end{array}$ \\
\hline $\begin{array}{l}\text { CS, } 1 \mathrm{df} \\
\text { Tillage } \times \mathrm{CS}, 3 \mathrm{df}\end{array}$ & $\begin{array}{l}0.71 \\
0.32\end{array}$ & $\begin{array}{l}0.72 \\
0.40\end{array}$ & $\begin{array}{l}0.30 \\
0.27\end{array}$ & $\begin{array}{l}0.64 \\
0.67\end{array}$ & $\begin{array}{l}0.41 \\
0.55\end{array}$ & $\begin{array}{l}0.23 \\
0.23\end{array}$ & $\begin{array}{l}0.32 \\
0.56\end{array}$ \\
\hline $\mathrm{CV}, \%$ & 4.3 & 5.6 & 3.9 & 3.1 & 2.5 & 1.9 & 2.9 \\
\hline
\end{tabular}

Table 1. Aggregate density of size classes at different tillage and crop sequence treatments in 1990.

$\uparrow$ Numbers in parentheses are mean aggregate diameter.

$\ddagger C-S-C$ is corn-soybean-corn, and $S-C-S$ is soybean-corn-soybean in 1987,1988 , and 1989, respectively.

If $A$ probability level $\leq 0.10$ was considered significant. 
ments. Organic $\mathrm{C}$ content for the top $80 \mathrm{~mm}$ of soil was $16.4 \pm 0.5,15.9 \pm 1.1,17.2 \pm 1.2$, and $15.7 \pm 0.9$ $\mathrm{g} \mathrm{kg}^{-1}$ for the chisel, disk, no-till, and plow treatments, respectively. Wittmuss and Mazurak (1958) found the organic matter content of intermediate-sized aggregates was greater than either smaller or larger aggregates in a Sharpsburg soil. Aggregate densities, averaged across tillage and crop sequence, significantly $(P<0.01)$ increased from 1.25 to $1.77 \mathrm{Mg} \mathrm{m}^{-3}$ as the aggregate diameter decreased from 6.38 to $0.162 \mathrm{~mm}$, respectively.

Covariance analysis is usually performed on a data set to adjust the treatment means for the covariant effect. In our analyses, however, the procedure was performed to compare values of $D$ for different levels of each treatment (Table 2). In these analyses the main effects of tillage and crop sequence and the interaction of tillage $x$ crop sequence test the equality of aggregate numbers at midpoints of the regression lines. Our discussion, however, will focus on the interactions of the covariant with tillage, crop sequence, and tillage $\times$ crop sequence, which indicate the differences between levels of each treatment for $D$.

Fractal dimension, which is calculated from aggregate-size distribution and is an indicator of soil fragmentation and subsequently of soil structure, was used to determine differences between tillage treatments and crop sequences. Lower $D$ values indicate a soil dominated by larger aggregates. For example, at prespring tillage (Day 98) in 1989, no-till $(D=2.767)$ had 2.3 times more 6.38-mm aggregates than plow $(D=3.306)$, while plow had three times more $0.162-\mathrm{mm}$ aggregates than no-till. These values were calculated from the regression values in Table 3 . Higher $D$ values indicate a soil dominated by smaller aggregates. Soil fragmentation was found to be fractal in the range of the aggregate sizes used.

Fractal dimension was significantly different among the tillage treatments at the post-autumn-tillage sampling time as indicated by the significant $\log d \times$ tillage interaction (Table 2). The fractal dimensions for plow and disk were smaller than for chisel at post-autumn tillage, indicating that the inversion of soil in these tillage systems created a medium dominated by large aggregates (Table 3). By early spring, however, the plowed soil was dominated by smaller aggregates, indicating a deterioration of aggregation over winter since the $D$ for plow at prespring-tillage in 1989 was $25 \%$ greater than at post-autumn tillage in 1988. The $D$ values for plow at all sampling times, except post-autumn tillage, were greater than no-till, indicating more fragmentation in the plow treatment. The low values of $D$ for plow at postautumn tillage in 1988 was probably caused by moving the lower layer of soil, with larger granules, to the surface during the plowing operation.

Analysis of variance performed on the $D$ values over time indicated a significant sampling time $\times$ tillage interaction $(P<0.01)$. The $D$ values determined in spring of 1989 (prespring tillage and emergence) were greater than post-autumn tillage for all tillage systems (Table 3), indicating soil fragmentation over winter in the order of plow > chisel $>$ disk > no-till. By physiological maturity, however, the $D$ values were significantly smaller than early spring in both years, indicating formation of larger aggregates during the growing season for all tillage systems. It seems that increased biological activity and subsequent production of metabolic byproducts, and also living plant roots, encouraged formation of larger aggregates during the growing season. The $D$ values for the tillage treatments at physiological maturity in 1989 followed the same trend as in 1988, but the values were smaller. The soil water content was greater in $1989 \mathrm{com}$ pared with 1988 (data not shown), which would increase the activity of microorganisms (Doran, 1987) and result in greater degradation of plant residues with a concomitant release of substrates, which may enhance the soil aggregation processes.

There were significant plow vs. no-till $\times$ crop se-

Table 2. Analysis of covariance for determination of fractal dimensions of different tillage and crop sequence treatments at different sampling times in 1988 and 1989.

\begin{tabular}{|c|c|c|c|c|c|c|c|c|}
\hline \multirow[b]{2}{*}{ Variable } & \multirow[b]{2}{*}{ df } & \multicolumn{4}{|c|}{1988} & \multicolumn{3}{|c|}{1989} \\
\hline & & $\begin{array}{c}\text { Precultivation } \\
(158) \dagger\end{array}$ & $\begin{array}{c}\text { Flowering } \\
\text { (205) }\end{array}$ & $\begin{array}{c}\text { Physiological } \\
\text { maturity } \\
(256)\end{array}$ & $\begin{array}{l}\text { Post autumn } \\
\text { tillage (303) }\end{array}$ & $\begin{array}{c}\text { Prespring } \\
\text { tillage (98) }\end{array}$ & $\begin{array}{c}\text { Emergence } \\
\text { (144) }\end{array}$ & $\begin{array}{c}\text { Physiological } \\
\text { maturity } \\
\text { (256) }\end{array}$ \\
\hline & & & & & $-\boldsymbol{P}$ & & & \\
\hline Replicate (Rep) & 5 & $0.65 \ddagger$ & 0.60 & 0.39 & 0.76 & 0.96 & 0.20 & 0.01 \\
\hline Tillage (Til) & 3 & $0.08(0.59)$ & $0.59(0.53)$ & $0.01(0.62)$ & $0.02(0.63)$ & $0.34(0.01)$ & $0.81(0.18)$ & $0.01(0.01)$ \\
\hline $\operatorname{Rep} \times$ Till & 15 & & & & & & & \\
\hline Crop sequence (CS) & 1 & $0.01(0.17)$ & $0.03(0.44)$ & $0.02(0.26)$ & $0.12(0.76)$ & $0.91(0.87)$ & $0.86(0.54)$ & $0.14(0.09)$ \\
\hline Till $\times C S$ & 3 & 0.99 & 0.70 & 0.56 & 0.22 & 0.93 & 0.75 & 0.78 \\
\hline Log diameter $(\log d)$ f & 1 & 0.01 & 0.01 & 0.01 & 0.01 & 0.01 & 0.01 & 0.01 \\
\hline $\log d \times$ Till & 3 & 0.88 & 0.23 & 0.19 & 0.06 & 0.01 & 0.36 & 0.05 \\
\hline Disk vs. no-till & 1 & 0.46 & 0.81 & 0.53 & 0.54 & 0.31 & 0.56 & 0.44 \\
\hline Plow vs. no-till & $\mathbf{i}$ & 0.73 & 0.10 & 0.05 & 0.94 & 0.01 & 0.24 & 0.08 \\
\hline Chisel vs. plow & $\mathbf{1}$ & 0.76 & 0.40 & 0.72 & 0.02 & 0.62 & 0.43 & 0.58 \\
\hline $\log d \times C S$ & $\mathbf{1}$ & 0.16 & 0.44 & 0.67 & 0.11 & 0.77 & 0.37 & 0.34 \\
\hline $\log d \times$ Till $\times C S$ & 3 & 0.32 & 0.28 & 0.37 & 0.84 & 0.91 & 0.48 & 0.17 \\
\hline Disk vs. no-till by CS & 1 & 0.69 & 0.36 & 0.18 & 0.50 & 0.59 & 0.48 & 0.28 \\
\hline Plow vs. no-till by CS & $\mathbf{1}$ & 0.07 & 0.05 & 0.09 & 0.49 & 0.84 & 0.23 & 0.24 \\
\hline Chisel vs. plow by CS & 1 & 0.33 & 0.42 & 0.56 & 0.90 & 0.66 & 0.17 & 0.26 \\
\hline$R^{2}$ & & 0.981 & 0.979 & 0.979 & 0.979 & 0.972 & 0.975 & 0.978 \\
\hline
\end{tabular}

$\dagger$ Numbers in parentheses are days of the year.

¥ A probability level $\leq \mathbf{0 . 1 0}$ is considered significant; for Till and CS, probabilities were determined from Type I sum of squares testing equality of the midpoints of regression lines, and probabilities in parentheses are determined from Type III sum of squares testing the equality of the intercepts.

I Covariant, $\log d=\log \left(d_{k} / d_{g}\right)$ where $d_{k}$ is the aggregate diameter of Class $k$ and $d_{g}$ is diameter of the largest aggregates. 
Table 3. Fractal dimension $(D=-$ slope) and intercept (Int.) of regression line of $\log$ of aggregate number vs. log of aggregate diameter/diameter of the largest aggregates for the tillage and crop sequence treatments at different sampling times in 1988 and 1989.

\begin{tabular}{|c|c|c|c|c|c|c|c|c|c|c|c|c|c|c|}
\hline \multirow[b]{3}{*}{ Variable } & \multicolumn{8}{|c|}{1988} & \multicolumn{6}{|c|}{1989} \\
\hline & \multicolumn{2}{|c|}{$\begin{array}{c}\text { Precultivation } \\
\text { (158) } \dagger\end{array}$} & \multicolumn{2}{|c|}{$\begin{array}{c}\text { Flowering } \\
\text { (205) }\end{array}$} & \multicolumn{2}{|c|}{$\begin{array}{c}\text { Physiological } \\
\text { maturity (256) }\end{array}$} & \multicolumn{2}{|c|}{$\begin{array}{l}\text { Post autumn } \\
\text { tillage (303) }\end{array}$} & \multicolumn{2}{|c|}{$\begin{array}{l}\text { Prespring } \\
\text { tillage (98) }\end{array}$} & \multicolumn{2}{|c|}{$\begin{array}{c}\text { Emergence } \\
\text { (144) }\end{array}$} & \multicolumn{2}{|c|}{$\begin{array}{l}\text { Physiological } \\
\text { maturity (265) }\end{array}$} \\
\hline & $D$ & Int. & $D$ & Int & $D$ & Int. & $D$ & Int. & $D$ & Int. & $D$ & Int. & $D$ & Int. \\
\hline $\begin{array}{l}\text { Tillage } \\
\text { Chisel } \\
\text { Disk } \\
\text { No-till } \\
\text { Plow } \\
\text { SEE } \ddagger\end{array}$ & $\begin{array}{l}2.793 \\
2.799 \\
2.752 \\
2.774 \\
0.045\end{array}$ & $\begin{array}{l}2.310 \\
2.296 \\
2.246 \\
2.342 \\
0.040\end{array}$ & $\begin{array}{l}2.765 \\
2.698 \\
2.713 \\
2.281 \\
0.046\end{array}$ & $\begin{array}{l}2.327 \\
2.398 \\
2.333 \\
2.302 \\
0.041\end{array}$ & $\begin{array}{l}2.808 \\
2.743 \\
2.701 \\
2.832 \\
0.047\end{array}$ & $\begin{array}{l}2.283 \\
2.300 \\
2.230 \\
2.294 \\
0.042\end{array}$ & $\begin{array}{l}2.798 \\
2.690 \\
2.651 \\
2.646 \\
0.045\end{array}$ & $\begin{array}{l}2.348 \\
2.397 \\
2.381 \\
2.314 \\
0.040\end{array}$ & $\begin{array}{l}3.264 \\
2.854 \\
2.767 \\
3.306 \\
0.060\end{array}$ & $\begin{array}{l}1.919 \\
2.242 \\
2.264 \\
1.893 \\
0.053\end{array}$ & $\begin{array}{l}2.889 \\
2.827 \\
2.871 \\
2.958 \\
0.053\end{array}$ & $\begin{array}{l}2.263 \\
2.300 \\
2.258 \\
2.206 \\
0.047\end{array}$ & $\begin{array}{l}2.756 \\
2.626 \\
2.677 \\
2.792 \\
0.047\end{array}$ & $\begin{array}{l}2.048 \\
2.250 \\
2.174 \\
2.071 \\
0.041\end{array}$ \\
\hline $\begin{array}{c}\text { Crop sequ } \\
\text { C-S-C } \\
\text { S-C-S } \\
\text { SEE }\end{array}$ & $\begin{array}{l}2.748 \\
2.811 \\
0.032\end{array}$ & $\begin{array}{l}2.271 \\
2.326 \\
0.028\end{array}$ & $\begin{array}{l}2.731 \\
2.767 \\
0.033\end{array}$ & $\begin{array}{l}2.324 \\
2.356 \\
0.029\end{array}$ & $\begin{array}{l}2.761 \\
2.781 \\
0.034\end{array}$ & $\begin{array}{l}2.253 \\
2.300 \\
0.030\end{array}$ & $\begin{array}{l}2.660 \\
2.733 \\
0.032\end{array}$ & $\begin{array}{l}2.366 \\
2.354 \\
0.028\end{array}$ & $\begin{array}{l}3.056 \\
3.039 \\
0.042\end{array}$ & $\begin{array}{l}2.075 \\
2.084 \\
0.037\end{array}$ & $\begin{array}{l}2.912 \\
2.864 \\
0.038\end{array}$ & $\begin{array}{l}2.242 \\
2.271 \\
0.033\end{array}$ & $\begin{array}{l}2.690 \\
2.735 \\
0.033\end{array}$ & $\begin{array}{l}2.170 \\
2.101 \\
0.029\end{array}$ \\
\hline
\end{tabular}

$\uparrow$ Numbers in parentheses are days of the year.

$\$$ SEE is standard error of estimates.

If $\mathrm{C}-\mathrm{S}-\mathrm{C}$ is com-soybean-com, and $\mathrm{S}-\mathrm{C}-\mathrm{S}$ is soybean-corn-soybean in 1987, 1988, and 1989, respectively.

quence contrasts for $D$ at precultivation, flowering, and physiological maturity in 1988 (Tables 2 and 4). The fractal dimensions in no-till were lower for $\mathrm{C}-\mathrm{S}-\mathrm{C}$ than S-C-S, indicating a better soil structure for the C-S-C crop sequence than S-C-S at these sampling times (Table 4). These differences may reflect the effect of the previous year's crop on soil aggregate formation in the crop sequences. For example, the previous crop was corn in C-S-C and, subsequently, the lower $D$ value for this treatment in the no-till may indicate the positive effect of corn on soil structure compared with soybean. The greater $D$ value for S-C-S, however, may indicate a negative effect of the previous year's soybean crop on soil structure. Fahad et al. (1982) concluded that the low geometric mean diameter of soil aggregates in continuous soybean was an indication of the negative effects of soybean roots in building a stable soil structure. In the plow system, however, the $D$ values were not different for the two crop sequence systems, indicating that the previous year's crop had little effect on soil structure in this tillage treatment. It appears that the greater mixing of residue with soil and the more rapid residue decomposition with plow reduced the effects of the previous crop on soil structure.

The intercepts of the regression lines represent the abundance of the largest aggregates [inverse log at log $\left(d_{k} / d_{\mathrm{g}}\right)=0$ ] in each treatment and are given in Table 3 . Eghball et al. (1993) showed that the intercept of the regression line, which was used to determine fractal dimension, indicated the abundance of the material being measured and could be used to determine quantitative differences between treatments. In this study, the intercepts were significantly different among tillage treat-

Table 4. Fractal dimension $(D)$ for no-till and plow under two crop sequences at various times in 1988.

\begin{tabular}{|c|c|c|c|c|c|c|}
\hline \multirow[b]{2}{*}{ Crop sequence $\dagger$} & \multicolumn{2}{|c|}{ Precultivation } & \multicolumn{2}{|c|}{ Flowering } & \multicolumn{2}{|c|}{$\begin{array}{c}\text { Physiological } \\
\text { maturity }\end{array}$} \\
\hline & no-till & plow & no-till & $\overline{\text { plow }}$ & no-till & plow \\
\hline $\begin{array}{l}\mathbf{C}-\mathbf{S}-\mathbf{C} \\
\mathbf{S}-\mathrm{C}-\mathrm{S}\end{array}$ & $\begin{array}{l}2.672 \\
2.831\end{array}$ & $\begin{array}{l}2.808 \\
2.739\end{array}$ & $\begin{array}{l}2.630 \\
2.797\end{array}$ & $\begin{array}{l}2.865 \\
2.777\end{array}$ & $\begin{array}{l}2.622 \\
2.780\end{array}$ & $\begin{array}{l}2.865 \\
2.799\end{array}$ \\
\hline
\end{tabular}

† C-S-C is corn-soybean-corn, and S-C-S is soybean-corn-soybean in 1987,1988 , and 1989 , respectively. ments at prespring tillage and at physiological maturity in 1989 (Table 2). Tillage treatments with lower fractal dimensions had higher intercepts, indicating a greater abundance of the largest aggregates. The intercepts were not different among the crop sequences at all sampling times except at physiological maturity in 1989 , where C-S-C had a larger intercept than S-C-S.

Tyler and Wheatcraft (1992) suggested that the use of a mass-based equation to estimate fractal dimension for particle-size distribution (assuming a constant particle density) would constrain $D$ between 0 and 3 , unlike the number-based equations. They argued that $D$ values $>3$ observed in other studies (Perfect and Kay, 1991; Rasiah et al., 1992; Tyler and Wheatcraft, 1989) may be artifacts of grain density and size assumptions. In these studies, the aggregate densities were assumed to be the same for all size classes and, as indicated in Table 1, that may not be a valid assumption. In our study, however, where we actually determined the density of aggregate size classes, we still observed $D$ values $>3$ for two tillage treatments and the crop sequences at one sampling time (prespring tillage). Comparison of the intercepts indicated that these treatments indeed had a lower number of larger aggregates and the results seem to be a valid indicator of the soil status. The $D$ values for the treatments at all other sampling times were $<3$.

\section{CONCLUSIONS}

Fractal analysis was a useful method of quantifying soil fragmentation and subsequently of expressing the quality of soil structure, which has previously been difficult to achieve. Fractal dimension was used as an indicator of soil fragmentation and of structure for detecting differences between tillage methods and crop sequences. Soil fragmentation differences observed between tillage treatments after autumn tillage became even greater over winter. In all tillage systems, the $D$ value increased over winter, indicating that the soil fragmentation increased and soil became dominated by smaller aggregates. The increase in $D$ over winter was in the order of plow > chisel $>$ disk $>$ no-till. Formation of larger aggregates increased as the growing season proceeded for all tillage systems. This was presumably because of breakdown of 
plant residue by microorganisms and living plant roots, which provided aggregate forming byproducts. It appears that corn increased formation of larger aggregates while soybean plants decreased it.

\section{REFERENCES}

Calvo, G.A. 1991. Influence of four tillage methods and two cropping sequences on soil structure as a function of time. M.S. thesis. Univ. of Nebraska, Lincoln.

Chepil, W.S. 1950. Methods of estimating apparent density of discrete soil grains and aggregates. Soil Sci. 70:351-362.

Doran. J.W. 1987. Microbial biomass and mineralizable nitrogen distributions in no-tillage and plowed soils. Biol. Fertil. Soils 5:68-75.

Eghball, B., J.R. Settimi, J.W. Maranville, and A.M. Parkhurst. 1993. Fractal analysis for morphological description of corn roots under nitrogen stress. Agron. J. 85:287-289.

Fahad, A.A., L.N. Mielke, A.D. Flowerday, and D. Swartzendruber. 1982. Soil physical properties as affected by soybean and other cropping sequences. Soil Sci. Soc. Am. J. 46:377381.

Mandelbrot, B.B. 1983. The fractal geometry of nature W.H. Freeman, San Francisco.

Miles-McDermott, N.J., W.T. Federer, M.P. Meredith, and Z.D. Feng. 1988. The analysis of covariance for split-unit and re- peated measures experiments using the GLM procedure in SAS/ STAT software. p. 1-24. Proc. Ânnu. SUGI Conf. 13th, Orlando, FL, 27-30 Mar. 1988. SAS Inst., Cary, NC.

Perfect, E., and B.D. Kay. 1991. Fractal theory applied to soil aggregation. Soil Sci. Soc. Am. J. 55:1552-1558.

Rasiah, V., B.D. Kay, and E. Perfect. 1992. Evaluation of selected factors influencing aggregate fragmentation using fractal theory. Can. J. Soil Sci. 72:97-106.

Rieu, M., and G. Sposito. 1991a. Fractal fragmentation, soil porosity, and soil water properties. I. Theory. Soil Sci. Soc. Am. J. 55:1231-1238.

Rieu, M., and G. Sposito. 1991b. Fractal fragmentation, soil porosity, and soil water properties: II. Applications. Soil Sci. Soc. Am. J. 55:1239-1244.

SAS Institute. 1985. SAS user's guide. Statistics. SAS Inst., Cary, NC.

Tyler, S.W., and S.W. Wheatcraft. 1989. Application of fractal mathematics to soil water retention estimation. Soil Sci. Soc. Am. J. 53:987-996.

Tyler, S.W., and S.W. Wheatcraft. 1992. Fractal scaling of soil particle-size distribution: Analysis and limitations. Soil Sci. Soc. Am. J. 56:363-369.

Winer, B.J. 1971. Statistical principles in experimental design. McGraw-Hill Co., New York.

Wittmuss, H.D., and A.P. Mazurak. 1958. Physical and chemical properties of soil aggregates in a Burnizem soil. Soil Sci. Soc. Am. Proc. 22:1-5. 